\title{
PELATIHAN BUDIDAYA JAMUR TIRAM DENGAN KONSEP URBAN FARMING UNTUK MASYARAKAT PERKOTAAN
}

\author{
Andi Iva Mundiyah, Ni Made Wirastika Sari, Sharfina Nabilah, dan Pande Komang \\ Suparyana \\ Fakultas Pertanian, Universitas Mataram \\ E-mail : andiva@unram.ac.id
}

\begin{abstract}
ABSTRAK
Budidaya jamur bukan merupakan hal yang baru bagi masyarakat Indonesia pada umumnya. Iklim negara kita yang panas dengan kelembaban yang cukup tinggi, merupakan kondisi yang ideal bagi tumbuhnya jamur tiram, namun ketersediaan jamur tiram dipasaran khususnya di Kota Makassar belum terlalu banyak dikarenakan masih kurangnya pembudidaya jamur tiram. Jamur tiram yang dijumpai di pusat perbelanjaan di Kota Makassar merupakan jamur yang berasal dari Pulau Jawa sehingga terkadang kondisinya sudah layu, menguning hingga berair. Kondisi ini menyebabkan harga jamur relatif lebih mahal, jika dibandingkan dengan harga jamur di daerah lain (pulau Jawa). Keterbatasan keterampilan dalam membudidayakan jamur menjadi salah satu penyebab terbatasnya persediaan stok jamur dipasar. Di pihak lain, pola pikir masyarakat tentang kegiatan bertani harus di lahan yang luas serta ketersediaan lahan untuk kegiatan budidaya di Kota Makassar mulai terbatas dengan maraknya pembangunan perumahan dan pusat perkantoran, padahal jamur tiram merupakan super food yang memiliki banyak manfaat bagi tubuh manusia. Tujuan dilakukannya kegiatan pelatihan ini untuk memberikan keterampilan kepada masyarakat khusus masyarakat Kota Makassar dalam berbudidaya jamur tiram dengan memanfaatkan keterbatasan lahan atau memanfaatkan pekarangan rumah. Kegiatan menggunakan motede Focus Disscusion group (FGD) berlangsung selama 3 (Tiga) hari dari tanggal 12-15 Januari 2020 bertempat di rumah salah satu anggota masyarakat. Pelatihan budidaya jamur tiram pada hari pertama yaitu persiapan dan pembuatan media tanam jamur tiram, hari kedua kegiatan inokulasi bibit jamur tiram ke media tanam yang telah siap dan hari ketiga evaluasi kegiatan dengan melihat kondisi media tanam jamur terdapat kontaminaasi atau tidak. Hasil kegiatan pelatihan ini sebagian peserta telah paham cara budidaya jamur tiram dengan menghasilkan media tanam jamur tiram yang tidak terkontaminasi oleh jamur lain. Media jamur tiram yang berhasil adalah media jamur tiram yang berwarna putih seperti kapas dan setelah 1 bulan akan keluar jamur tiram yang dikenal dengan pin head.
\end{abstract}

Kata Kunci : jamur tiram, urban farming, kewirausahaan, perkotaan

\section{PENDAHULUAN}

Pesatnya laju pertumbuhan populasi di perkotaan akan menimbulkan masalah lingkungan, mulai dari konversi lahan sampai degradasi kualitas lingkungan akibat polusi dan sampah. Apabila kondisi pertumbuhan populasi penduduk lebih besar dibandingkan laju produksi bahan pangan, maka akan terjadi bencana krisis pangan. Jumlah bahan pangan yang tidak cukup secara paralel akan berdampak pada ketergantungan antara suatu kawasan/wilayah terhadap kawasan lain. Hal ini terjadi terutama untuk 
wilayah perkotaan negara-negara berkembang, dimana wilayah tersebut semakin menjadi pusat penduduk serta permukiman dan kumpulan orang-orang dengan keragaman etnik (Jalil, 2005). FAO (2008) memprediksi bahwa pada tahun 2020, sekitar $75 \%$ penduduk di negara-negara berkembang di Afrika, Asia, dan Amerika Latin akan tinggal di kawasan perkotaan. Kondisi ini mendorong pemerintah maupun masyarakat di kawasan perkotaan harus mulai mencoba untuk memenuhi kebutuhan pangan secara mandiri (Noorsya dan Kustiwan, 2013) serta memperbaiki kondisi lingkungan agar tercipta lingkungan yang sehat dan berkualitas. Salah satu solusinya adalah dengan menerapkan urban farming.

Perkembangan pertanian perkotaan di Indonesia khususnya di Ibu Kota Jakarta sebetulnya sudah mulai terlihat pasca krisis ekonomi 1997-1998. (Fauzi, 2016). Dalam beberapa tahun belakangan ini, Salah satu bentuk pemberdayaan masyarakat adalah berupa memberikan kesadaran terhadap adanya peluang peluang baru dalam meningkatkan kesejahteraan hidupnya dan bisa juga dengan memberikan pelatihan-pelatihan dalam membuka usaha secara mandiri (Basuki dkk, 2020). tren urban farming semakin diminati oleh masyarakat yang tinggal di kota-kota besar seperti Jakarta, Surabaya, Makassar. Kemajuan diberbagai bidang akibat kemajuan ilmu pengetahuan dan teknologi merupakan tantangan besar bagi anak muda untuk senantiasa mampu memanfaatkan dan mengelola lingkungannya. Oleh karena itu diperlukan adanya berbagai program yang dapat dilakukan oleh kaum anak muda dalam rangka peningkatan kesejahteraan (Maulidie dkk, 2020). Urban farming yang berarti bercocok tanam di lingkungan rumah perkotaan dianggap beriringan dengan keinginan masyarakat kota untuk menjalani gaya hidup sehat. Hasil panen dari urban farming lebih menyehatkan dikarenakan tidak menggunakan pupuk kimia dan pestisida sintetis. Urban farming memiliki dampak yang lebih besar bagi kelangsungan masyarakat perkotaan. Sejumlah penelitian menyebutkan bahwa urban farming dapat menjadi konsep pertanian ideal dimasa depan. Menjawab krisis ketersediaan lahan untuk bercocok tanaman di perkotaan. Hasil penelitian dari Atik dan Johanes (2017) menyimpulkan solusi terbaik untuk mengatasi keterbatasan lahan akibat jumlah penduduk yang terus meningkat adalah dengan pembangunan secara vertikal selain itu urban farming didalamnya dirancang untuk mengatasi 
isu keterbatasan lahan pertanian. Berbagai sistem pertanaman urban farming seperti vertikultur, hidroponik, dan aquaponik dapat dengan mudah di area terbatas.

Fakta tersebut menunjukkan bahwa usahatani di perkotaan dapat memberikan lapangan pekerjaan dan menjadi sumber penghasilan masyarakat serta menyangga kestabilan ekonomi di dalam keadaan kritis dan berkaitan langsung dengan upaya penaggulangan kemiskinan serta penciptaan lingkungan yang lestari (Sampeliling et al., 2012).

Pertanian perkotaan hadir sebagai solusi dalam kelangsungan pangan di kotakota besar di Indonesia. Tidak bisa dihindarkan bahwa suatu kota besar memerlukan daerah disekitarnya untuk memasok bahan makanan setiap harinya. Menurut Puriandi dan Indrajati (2013), 97\% kebutuhan pangan kota Bandung dipasok oleh daerah diluar kota Bandung seperti Kabupaten Bandung, Cianjur, Karawang, Subang, Sumedang, Garut, Majalengka hingga Provinsi Jawa Tengah. Hal ini tentu menjadi masalah serius ketika terbatasnya ketersediaan dan akses pangan terjadi akibat dari tidak meratanya pendapatan penduduk yang berakhir pada konflik kemiskinan.

Budidaya jamur bukan merupakan hal yang baru bagi masyarakat Indonesia pada umumnya. Iklim negara kita yang panas dengan kelembaban yang cukup tinggi, merupakan kondisi yang ideal bagi tumbuhnya berbagai jenis jamur. Beberaja jenis jamur yang telah dikenal dan dibudidayakan secara luas di Indonesia antara lain jamur merang (Volvariela volvaceae), jamur kuping (Auricularia aricula), jamur shitake (Lentinula edodes) dan jamur tiram putih (Auricularia polytricha) (Susilawati \& Raharjo, 2010)

Ketersediaan jamur tiram dipasaran khususnya di Kota Makassar belum terlalu banyak dikarenakan masih kurangnya pembudidaya jamur tiram. Jamur tiram yang dijumpai di pusat perbelanjaan di Kota Makassar merupakan jamur yang berasal dari Pulau Jawa sehingga terkadang kondisinya sudah layu, menguning hingga berair. Kondisi ini menyebabkan harga jamur relatif lebih mahal, jika dibandingkan dengan harga jamur di daerah lain (pulau Jawa). Keterbatasan keterampilan dalam membudidayakan jamur menjadi salah satu penyebab terbatasnya persediaan stok jamur dipasar. Di pihak lain, pola pikir masyarakat tentang kegiatan bertani harus di lahan yang luas namun ketersediaan lahan untuk kegiatan budidaya di Kota Makassar mulai terbatas dengan maraknya pembangunan perumahan dan pusat perkantoran, padahal jamur tiram merupakan super food yang memiliki 
banyak manfaat bagi tubuh manusia. Selain itu jamur tiram juga merupakan sumber pangan organik bebas pestisida (Sutarman, 2012).

Berdasarkan paparan analisis situasi dan permasalahan diatas, maka rumusan masalah yang akan diselesaikan dalam program pengabdian ini adalah bagaimana pemanfaatan lahan terbatas untuk budidaya jamur tiram untuk masyarakat perkotaan?

Tujuan Kegiatan pengabdian kepada masyarakat ini adalah untuk memberikan pelatihan budidaya jamur tiram dengan keterbatasan lahan untuk masayarakat perkotaan.

Sasaran dari kegiatan pengabdian masyarakat ini adalah masyarakat di Kecamatan Panakkukang Kota Makassar. Kecamatan Panakkukang merupakan salah satu kecamatan terpadat di Kota Makassar dengan ketersedian lahan yang terbatas untuk kegiatan pertanian.

\section{METODE}

\section{Metode Pelaksanaan Kegiatan}

Kegiatan pengabdian ini dilakukan dalam bentuk pelatihan budidaya jamur tiram selama 3 hari dari taggal 12-15 Januari 2020. Pelatihan budidaya jamur tiram terdiri dari praktik pembuatan media tanama jamur tiram, proses inokulasi bibit, proses inkubasi, proses pemanenan jamur tiram siap konsumsi.

Kegiatan pengabdian ini direncanakan selama 3 (tiga) hari, sebagai berikut:

1. Kegiatan hari pertama yaitu a) Penentuan lokasi tempat budidaya jamur tiram dan kegiatan pelatihan berlangsung. Setelah itu dilanjutkan dengan pembersihan lokasi dan sterilisasi lokasi. b) persiapan rak yang akan digunakan untuk menaruh media tanam jamur tiram nantinya. Rak dapat menggunakan bambu atau bisa dari besi ringan tergantung kesiapan dana. c) penyemprotan sekali lagi untuk memastikan lokasi yang akan digunakan untuk kegiatan budidaya jamur tiram bebas dari bakteri yang akan menyebabkan kontaminasi pada jamur tiram.

2. Kegiatan hari kedua yaitu a) Pembuatan media tanam yang terdiri dari dedak, serbuk gergaji, kapur. b) sterilisasi media tanam jamur selama 3-4 jam (satu tabung gas kecil habis). c) kegiatan pendinginan media tanam yang telah disterilisasi sebelum dilakukan kegiatan inokulasi bibit jamur di hari berikutnya.

3. Kegiatan hari ketiga adalah kegiatan inokulasi bibit jamur pada media tanam. Kegiatan ini merupakan tahapan terpenting dan memiliki 
tingkat risiko kegagalan yang cukup tinggi sehingga diperlukan kehatihatian dalam melakukannya. Media jamur tiram yang telah diinokulasi diletakkan pada rak yang telah dipersiapkan hingga media jamur tiram memutih keseluruhan $( \pm 1$ bulan).

Evaluasi kegiatan pengabdian akan dilakukan secara berkala selama kegiatan pelatihan berlangsung hingga kegiatan pelatihan selesai. Setiap tahapan akan dievaluasi dengan cara yang berbeda. antusias masyarakat selama kegiatan pelatihan berlangsung menjadi salah satu indikator keberhasilan pengabdian ini. Indikator keberhasilan pelaksanaan kegiatan pengabdian akan diukur dengan tingkat keterampilan dan pemahaman peserta, yaitu lebih dari $60 \%$ peserta memiliki pemahaman dan keterampilan dalam budidaya jamur tiram dan kontaminiasi pada media tanam jamur tiram dibawah $50 \%$.

Partisipasi masyarakat dalam kegiatan ini diantaranya adalah sebagai peserta aktif dan penyedia tempat pelaksanaan kegiatan.

\section{HASIL DAN PEMBAHASAN}

\section{Pelaksanaan Kegiatan Pengabdian}

Kegiatan pengabdian kepada masyarakat ini telah berhasil dilaksanakan dengan sukses pada tanggal 12-15 Januari 2020 di Rumah Bapak Fuad Kelurahan Tamalate Kecamatan Panakkukang Kota Makassar. Rumah Bapak Fuad dipilih karena keinginan dari yang bersangkutan ingin memanfaatkan pekarangan rumahnya untuk budidaya jamur karena kegeramannya mengkonsumsi dan mengetahui manfaat dari jamur tiram bagi kesehatan. Pekarangan Bapak Fuad berukuran $3 \mathrm{~m} \times \mathrm{m}$ sehingga konsep budidaya jamur tiram dapat dilakukan karena tidak membutuhkan lahan yang luas.

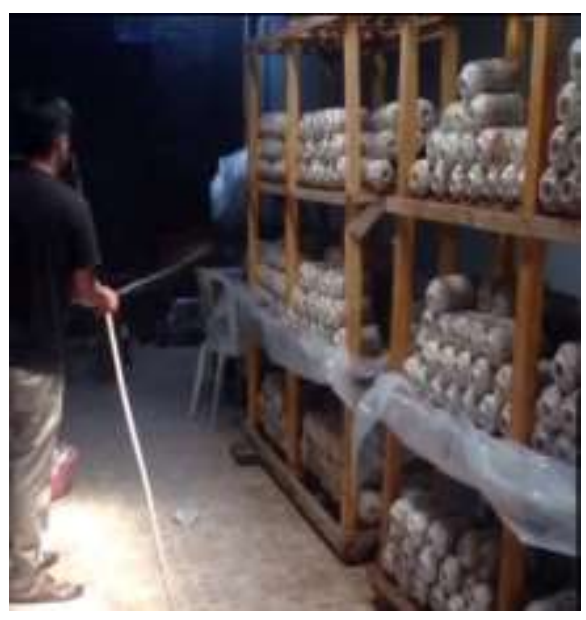

Gambar 1. Lokasi budidaya jamur tiram di rumah Bapak Fuad

Kegiatan pengabdian yang telah dilaksanakan berfokus pada peningkatan keterampilan dan pengetahuan tentang budidaya jamur tiram serta mengedukasi masyarakat kota untuk memanfaatkan lahan yang terbatas untuk kegiatan bertani dengan konsep urban farming. Materi pengabdian disampaikan oleh Andi Iva 
Mundiyah, S.P., M.Si. yang menjelaskan pemanfaatan lahan sempit dengan konsep urban farming melalui budidaya jamur tiram. Materi dilanjutkan dengan dengan praktik.

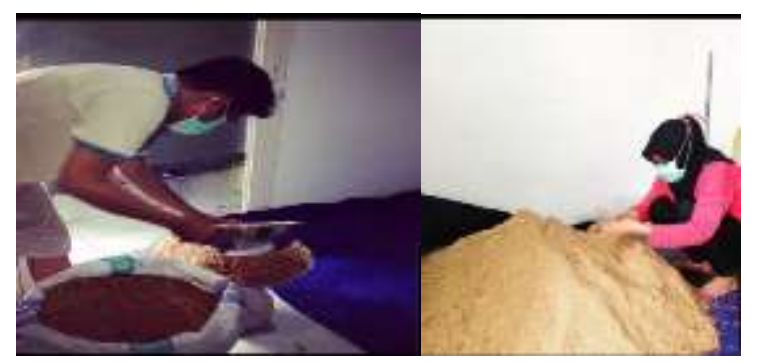

Gambar 2. Pencampuran bahan untuk media tanam jamur tiram

\section{Pada hari pertama kegiatan}

pelatihan budidaya jamur tiram dimulai dengan pembersihan lokasi dan sterilisasi lokasi, persiapan rak yang akan digunakan untuk menaruh media tanam jamur tiram nantinya, dilanjutkan penyemprotan sekali lagi untuk memastikan lokasi yang akan digunakan untuk kegiatan budidaya jamur tiram bebas dari bakteri yang akan menyebabkan kontaminasi pada jamur tiram. Pada hari kedua kegiatan yang dilakukan pembuatan media tanam yang terdiri dari dedak, serbuk gergaji, kapur, sterilisasi media tanam jamur selama 3-4 jam (satu tabung gas kecil habis), kegiatan pendinginan media tanam yang telah disterilisasi sebelum dilakukan kegiatan inokulasi bibit jamur di hari berikutnya. Dan pada hari ketiga inokulasi bibit jamur pada media tanam.
Kegiatan ini merupakan tahapan terpenting dan memiliki tingkat risiko kegagalan yang cukup tinggi sehingga diperlukan kehati-hatian dalam melakukannya.

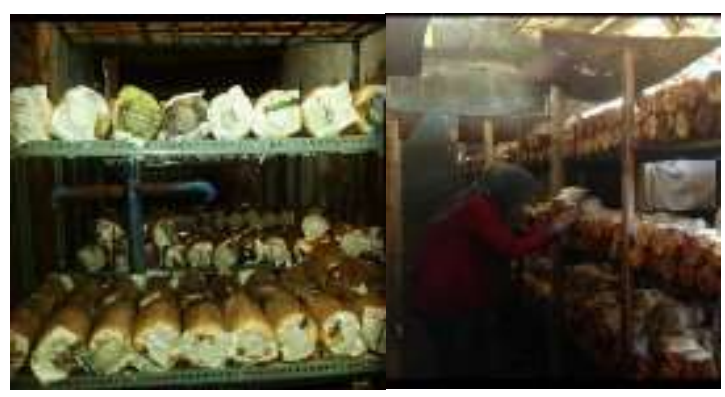

Gambar 3. Media jamur tiram yang sudah diinokulasi dan dalam masa inkubasi hingga panen

Selama pelaksanaan kegiatan peserta mengikuti dengan antusias. Sebagian besar santri belum pernah praktik budidaya jamur tiram. Pengalaman pertama membuat peserta tidak sungkan untuk mengajukan pertanyaan terutama tentang inokulasi bibit jamur. Pertanyaan yang dimaksud diantaranya adalah sebagai berikut : bagaimana ciri-ciri media jamur tiram yang terkontaminasi, jika media jamur terkontaminasi apa yang harus dilakukan, berapa lama waktu panen jamur tiram, dan bagaimana cara pemanenan jamur tiram yang baik.

\section{Evaluasi Pelaksanaan Kegiatan Pengabdian \\ Kegiatan pengabdian kepada masyarakat ini secara umum dapat berlangsung dengan lancar, dimulai dari}


perencanaan sampai dengan

pelaksanaan kegiatan. Masyarakat yang menjadi sasaran dari kegiatan pengabdian antusias dengan ada kegiatan pelatihan budidaya jamur tiram. Selanjutnya kami berharap masyarakat dapat membagi ilmu yang didapat dari pelatihan kepada keluarganya atau teman-temannya sehingga tidak ada lagi alasan untuk melakukan kegiatan bertani dengan alasan keterbatasan lahan di daerah Kota Makassar. Dari kegiatan pelatihan ini keberhasilan beberapa orang yang mengikuti kegiatan dapat menumbuhkan bibit jamur yang ditanam dan memanen hasilnya, salah satunya adalah Bapak Fuad.

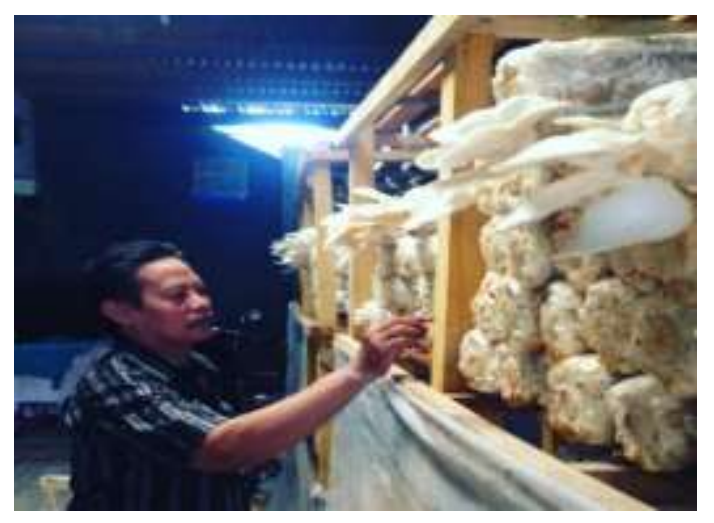

Gambar 4. Jamur tiram siap panen

\section{KESIMPULAN DAN SARAN}

\section{Kesimpulan}

Kegiatan pengabdian kepada masyarakat telah selesai dilaksanakan pada tanggal 12-15 Januari 2020 berlokasi di Rumah Bapak Fuad. Kegiatan budidaya jamur tiram dengan konsep urban farming dengan pemanfaatan pekaran rumah untuk memehuni kebutuhan pangan keluarga dalam hal ini jamur tiram putih. Peserta kegiatan pengabdian adalah masyarakat yang berada di sekitar wilayah rumah dari Bapak Fuad. Peserta mengikuti kegiatan pengabdian dengan baik dan antusias. Materi pengabdian adalah praktik budidaya jamur tiram dengan memanfaatkan lahan yang terbatas di pekarangan rumah.

\section{DAFTAR PUSTAKA}

Atik, D.N. dan Johanes K (2017). Urban Farming dalam Kampung Vertikal sebagai Upaya Efesiensi Keterbatasan Lahan. Jurnal Sains dan Seni Pomits Vol. 6 No. 2. Hal 95-99.

Basuki, Vitria A., Susiladewi. (2020). Memberdayakan Masyarakat Desa Melalui Pemberian Keterampilan dan Pendampingan Perubahan Sikap. Jurnal Pengabdian Al-Ikhlas Vol. 5 No. 2. Hal 182-187.

Food and Agriculture Organization (FAO). (2008). Urban Agriculture For Sustainable Poverty Alleviation and Food Security. 84p.

Fauzi, A.R., Annisa, N.I., Heny, A. (2016). Pertanian Perkotaan : Urgensi, Peranan, Dan Praktik Terbaik. Jurnal Agroteknologi Vol. 10 No, 12016. Hal 49-62.

Jalil, A. (2005). Kota: Dari Perspektif Urbanisasi. Jurnal Industri dan Perkotaan Volume IX Nomor 15. Hal 833-845.

Maulidie, M., Saputera, A., Sari, A.K., 
Febrianti, D.R., Niah, R., Kumalasari, E (2020). Program Bina Desa Dalam Pemberdayaan Masyarakat Untuk Pemanfaatan Tanaman Obat Keluarga Di Desa Tatah Layap Kabupaten Banjar. Jurnal Pengabdian Al-Ikhlas Vol. 6 No. 1. Hal 48-53

Noorsya, AO dan I Kustiwan. (2013). Jurnal Perencanaan Wilayah dan Kota B. SAPPK ITB. Bandung. Hal 89-99.

Puriandi F. dan PN Indrajati. (2013). Proses Perencanaan Kegiatan Pertanian Kota Yang Dilakukan Oleh Komunitas Berkebun Di Kota Bandung Sebagai Masukan Pengembangan Pertanian Kota Di Kawasan Perkotaan. Jurnal Perencanaan Wilayah dan Kota. Vol. 1 No. 2. Hal 497-506
Sampeliling et al., (2012). Kebijakan Pengembangan Pertanian Kota Berkelanjutan : Studi Kasus Di DKI Jakarta. Jurnal Analisis Kebijakan Pertanian. Vol. 10 No. 3. Hal 257267.

Susilawati dan B. Raharjo. (2010). Petunjuk teknis, budidaya jamur tiram (Pleourotus ostreatus var florida) yang ramah lingkungan (Materi Pelatihan Agribisnis bagi KMPH). Report No.50.STE.Final.BPTP Sumatera Selatan.

Sutarman. (2012). Keragaan dan produksi jamur tiram putih (Pleurotus Ostreatus) pada media serbuk gergaji dan ampas tebu bersuplemen dedak dan tepung jagung. Jurnal Penelitian Pertanian Terapan. 12(3): 163-168. 